$10-2-2020$

\title{
Hands-off Religion in the Early Months of COVID-19
}

Samuel J. Levine

Touro Law Center, slevine@tourolaw.edu

Follow this and additional works at: https://digitalcommons.tourolaw.edu/scholarlyworks

Part of the Civil Procedure Commons, Constitutional Law Commons, Courts Commons, First

Amendment Commons, Religion Law Commons, and the Supreme Court of the United States Commons

\section{Recommended Citation}

Levine, Samuel J., "Hands-off Religion in the Early Months of COVID-19" (2020). Scholarly Works. 680.

https://digitalcommons.tourolaw.edu/scholarlyworks/680

This Article is brought to you for free and open access by the Faculty Scholarship at Digital Commons @ Touro Law Center. It has been accepted for inclusion in Scholarly Works by an authorized administrator of Digital Commons @ Touro Law Center. For more information, please contact Iross@tourolaw.edu. 


\title{
Hands-Off Religion in the Early Months of COVID-19
}

\author{
Samuel J. Levine
}

For decades, scholars have documented the United States Supreme Court's "hands-off approach" to questions of religious practice and belief, pursuant to which the Court has repeatedly declared that judges are precluded from making decisions that require evaluating and determining the substance of religious doctrine. At the same time, many scholars have criticized this approach, for a variety of reasons. The early months of the COVID-19 outbreak brought these issues to the forefront, both directly, in disputes over limitations on religious gatherings due to the virus, and indirectly, as the Supreme Court decided important cases turning on religious doctrine. Taken together, judicial rulings and rhetoric in these cases illustrate ways in which the hand-off approach remains, at once, both vibrant and vulnerable to critique.

The hands-off approach is premised on the notion that, as a matter of both constitutional principle and judicial prudence, courts should not be in the position of resolving questions relating to the substantive nature of a religious practice or belief. Whatever the justifications, the ramifications of the hands-off approach are substantial and wide-ranging - and, arguably, problematic. For example, in some cases, the refusal to evaluate the substantive nature of a religious claim may prevent judges from protecting otherwise valid interests of less powerful groups or individuals. In deciding church property disputes or claims of employment discrimination, a court's unwillingness to closely examine religious doctrine may result in maintaining the status quo, thereby allowing a powerful segment of a divided church or a powerful religious employer to remain immune from potentially meritorious claims.

In other cases, the failure to take a close and nuanced look at a religious practice may lead judges to apply a binary analysis to free exercise and Religious Freedom Restoration Act (RFRA)/ Religious Land Use and Institutionalized Persons Act (RLUIPA) claims, favoring either the religious claimant or the government regardless of the precise nature or significance of the religious practice at issue. Conversely, in response to these and other potentially adverse consequences, judges - including, at times, Supreme Court Justices - may defy the hands-off approach altogether, substituting their own assessment of a religious practice or belief in place of that of a religious adherent.

A number of cases decided during the early months of the COVID-19 crisis, including two leading Supreme Court cases, seem to amplify many of the problematic aspects of the Court's hands-off approach to questions of religious practice and belief. In particular, on July 8, 2020, the Court handed down its decisions in two of the most notable and contested cases of the term: Little Sisters of the Poor Saints Peter and Paul Home v. Pennsylvania, and Our Lady of Guadalupe School v. Morrissey-Berru (OLG).

Little Sisters was a closely watched case in large part because it focused on several issues of considerable public controversy: The Patient Protection and Affordable Care Act of 2010, mandates for requiring organizations to provide coverage for contraceptive methods, and regulations exempting religious organizations from the contraceptive mandate. Adding to the 
significance of Little Sisters, the case represented the newest chapter in ongoing litigation that had already produced two major Supreme Court decisions: Burwell v. Hobby Lobby and Zubik v. Burwell. In fact, the debate between Justice Alito and Justice Ginsburg in Little Sisters essentially replayed — and nearly replicated — their debate over the hands-off approach in Hobby Lobby.

In a concurring opinion in Little Sisters, Justice Alito, joined by Justice Gorsuch, quoted Hobby Lobby to emphasize that, in evaluating a religious claim under the substantial burden prong of RFRA, a court must ask: "would compliance cause the objecting party to violate its religious beliefs, as it sincerely understands them?" Thus, Justice Alito relied on the hands-off approach to require judicial deference to a religious adherent's characterization of a religious belief, so as not to violate the principle that "'federal courts have no business addressing ... whether the religious belief asserted in a RFRA case is reasonable." In short, "'it is not for us to say that their religious beliefs are mistaken or insubstantial."'

In response, Justice Ginsburg, in a dissent joined by Justice Sotomayor, argued that "[t]oday, for the first time, the Court casts totally aside countervailing rights and interests in its zeal to secure religious rights to the nth degree." Specifically, Justice Ginsburg noted, "[t]he expansive religious exemption at issue here imposes significant burdens on women employees." Moreover, according to the dissent, under the previously incorporated religious accommodation, "the objecting employer is absolved of any obligation to provide the contraceptive coverage to which it objects .... This arrangement 'furthers the Government's interest [in women's health] but does not impinge on the [employer's] religious beliefs." As in her dissent in Hobby Lobby, out of concern for the burden placed on others, Justice Ginsburg seemed to defy the hands-off approach, demonstrating a willingness to second-guess religious adherents' characterizations of the impact of a law on their own religious practice and belief.

A similar dynamic played out in OLG, as the Court returned to another previous decision, Hosanna-Tabor v. EEOC, which had recognized the ministerial exception. The holding in Hosanna-Tabor was premised, in large part, on the Court's hands-off approach to church property disputes, which was, in turn, based on the proposition that judges should not interfere with the interpretation of church doctrine. In OLG, however, the Court was tasked with defining the contours of the ministerial exception.

Here, Justice Thomas echoed his concurrence in Hosanna- Tabor to again advocate a broad application of the hands-off approach. This time, in a concurrence joined by Justice Gorsuch, Justice Thomas "reiterate[d his] view that the Religion Clauses require civil courts to defer to religious organizations' good-faith claims that a certain employee's position is ministerial[,]" positing that "[w]hat qualifies as 'ministerial' is an inherently theological question, and thus one that cannot be resolved by civil courts through legal analysis." Justice Thomas insisted that judges must "heed the First Amendment," which "commands civil courts to decide [legal] disputes without resolving underlying controversies over religious doctrine."

In a sharply worded dissent, Justice Sotomayor, joined by Justice Ginsburg, faulted the majority and Justice Thomas for "trad[ing] legal analysis for a rubber stamp [ ]" of the claims of religious 
employers, "all but abandon[ing] judicial review." Expressing a position diametrically opposed to Justice Thomas's - and somewhat at odds with the hands-off approach—Justice Sotomayor declared that the Court's decision "permit[s] religious entities to discriminate widely and with impunity for reasons wholly divorced from religious beliefs." Again, whatever the justification for the hands-off approach, according to the dissenters, broad deference to substantive religious claims may have the deleterious practical effect of unfairly impinging upon the rights of others.

Finally, during the months in which these important cases were argued and decided - the early months of the COVID-19 crisis - a number of lower courts were confronted with other cases, directly stemming from the pandemic, that likewise implicated the hands-off approach to questions of religious practice and belief. Across the United States, religious claimants challenged governmental limitations on religious gatherings, which had been implemented to protect public health and safety. During this time, however, governments permitted many other forms of public gathering, suggesting the need for a closer look at the restrictions on religion. Different attitudes toward the hands-off approach to questions of religious practice and belief may help explain a stark difference in judicial rulings and judicial rhetoric in two of these cases.

In June, writing for the Seventh Circuit, Judge Easterbrook appeared to defy the hands-off approach, declaring that, unlike soup kitchens and housing for the homeless, which "require[ ] teams of people to work together in physical spaces, ... large in-person worship services [can be replaced] by smaller gatherings, radio, and TV worship services, drive-in worship services, and the Internet." In short, "churches can feed the spirit in other ways." Of course, religious adherents would likely disagree with — and may resent—Judge Easterbrook's analysis, finding that he imposed on them his understanding of the religious burden they faced, rather than accepting their characterization of the necessities of their own religious practice.

Indeed, Judge Easterbrook's analysis poses a striking contrast to a Sixth Circuit case, decided just one month earlier, which faithfully applied the hands-off approach to questions of religious practice and belief. As the Sixth Circuit acknowledged, "[s]ure, the Church might use Zoom services or the like." However, the court added, "who is ... to say that every member of the congregation must see it as an adequate substitute for what it means when 'two or three gather in my Name,' or what it means when 'not forsaking the assembling of ourselves together." As the court further explained, "that's exactly what the federal courts are not to judge- how individuals comply with their own faith as they see it. "

Taken together, these cases demonstrate the abiding relevance - and limitations - of the handsoff approach to questions of religious practice and belief, in both ordinary and extraordinary times. 